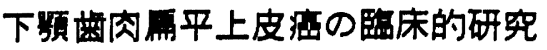

\author{
戸塚靖則・水越莱监・中村博行・畔田 其 \\ 工藤元耧・谷健一・山下微郎・宫田内 \\ 早川邦雄"・有末真*・井上晨夫男*
}

\section{Clinical studies of the squamous cell carcinoma of the lower gum}

\author{
Yasunori Totsuka - Takanori Mizukoshi - Hiroyuki Nakamura \\ Mitsugu Kuroda - Motonori Kudo - Kenichi Notanı \\ Tetsuro Yamashita - Kinai Tomita - Kunio Hayakawa" \\ Makoto ARISUE* • Nobuo INOUE*
}

\begin{abstract}
A clinical study was made of 69 cases, 50 male and 19 female of squamous cell carcinoma of the lower gum treated at the Oral Surgery Department of Hokkaido University, School of Dentistry between 1970 January and 1983 December.

Ages at first visit ranged from 29 to 83 years old but about $95 \%$ were over 50 years old. The majority had clinically advanced disease. Fifty four had radiologically abnormal findings of alveolar crest or mandible, and 30 had clinically metastasis lymph node at the first diagnosis.

The three year absolute cure rate for all cases was $54.9 \%$. In the comparison of treatment modality, the cure rate treated by surgery was clearly superior to that by radiation therapy and/or chemotherapy: The cure rate of the former was $75.0 \%$ and that of the latter was $21.1 \%$. Post-operative tumor control rate was related to the radiological findings of the mandible. The recurrent rate of patients who had radiologically an irregular lytic destruction of the mandible was $42 \%$ and that of patients who exhibited an erosion or change of the alveolar crest or mandible was $15 \%$. These results indicate that wide resection with plenty of safety margin is necessary in lower gum cancer that radiologically had irregular lytic destruction.
\end{abstract}

Key words: squamous cell carcinoma, lower gum cancer, gingival carcinoma

緒

\section{言}

下顎歯肉癌は口腔癌のなかでは舌癌, 口腔底癌につい、 で多く， 口腔癌の $20 〜 30 \%$ を占めると考えられている

北海道大学曾学部口腔外科学第 1 諳座 （主任：富田喜内救授）

* 北海道大学龇学部口腔外科学第 2 講座 （主任：河村正昭教授）

Department of Oral Surgery I, School of Dentistry, Hokkaido University (Chief: Prof. Kinai Tomita)

* Department of Oral Surgery II, School of Dentistry, Hokkaido University (Chief: Prof. Masaaki Kawamura)

受付日：昭和59年 9 月 6 日

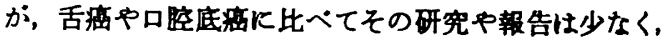

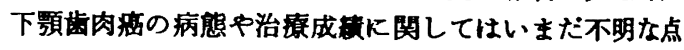
が少なくない.とくに下頭齿肉密においては扁平上皮高 の占める割合か汪的に多く，その病態や治㫫成責を明

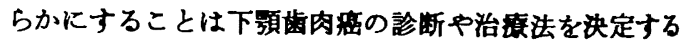
らえできわめて重要であると考えられるが，従来の報告 をみるといわゆる下額骨中心性嘧を含む下預我全体を対

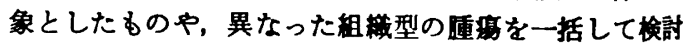
しているものが多く，下䫫齿肉扁平上皮就のみを対象と したものはきわめて少ない.そこでわれわれは下顎齿肉 扁平上皮癌の病態と治癔成耫を明らかにする目的で，北 海道大学齿学部口腔外科において治㞠した下顥齿肉扁平 上皮癌 1 次例を対象として臨床的锶察と治療成辕の検討 を行った。 
対

昭和45年 1 月から昭和58年12月までの14年間に北海道

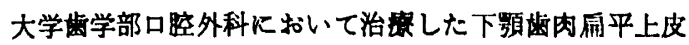
楛 1 次症例69例を対象とした。このなかには日後部に生 したと考えられたるの 4 例を含んでいるが，いわゆる下 買骨中心性瘦と考えられた症例は含んでいない、なお 1 例は当科初診時两側下影目部ならびに左側上部自齿部 に，独立した腫痽がみられた多発性䖵症例であった。し たかっって対象とした症例は69例，腫将は70例である。ち なみに同期間中に当科で治家した口腔痁 1 次症例 301 例 中下顥齿肉癌は 74 例 (24.6\%) で，扁平上皮癌はその $93.2 \%$ を占めていた（交1）.

\section{結果}

\section{1. 性別，年蝡別頻度}

性別は男性50例，女性19例で，男女比は2.6:1 と男 性に多かった．初診時の年峆は29煘〜83歳であったが， 平均年龄は62.6歳と高く，50歳以降のものが94. $2 \%$ を占 めていた，好発年哑は男女とも60藏代で，全体の $40.6 \%$ を占めていた（表 2 ）。なお 29 歳，男性症例は，初診時 左側下顎曰歯部と硬口蓋部に独立した尰疸がみられた多 発性癌症例であった。

\section{2. 既往症・合併症}

69例中27例 (39.1\%) は下頭齿肉瘦の治療方針に影警 を与える既往症や合併症を有していた.この5ち 6 例は 専門医での診察や検查結果から手術は禁忌と診断され, 他の21例では下靧畿肉癌の治療に先行ないし並行して合 併症に対する治療が必要であった。

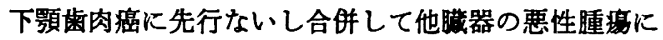

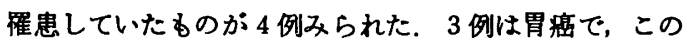

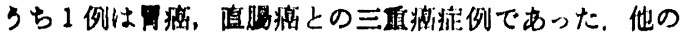
1 例は中咽暊度であった（表 14）。

\section{3. 初甡症状・主杽}

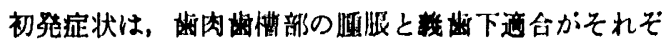

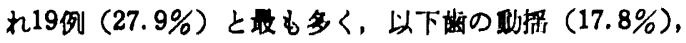

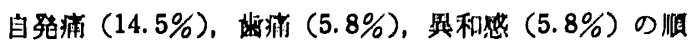

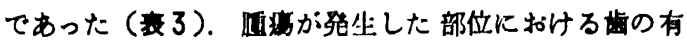

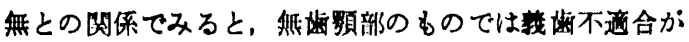

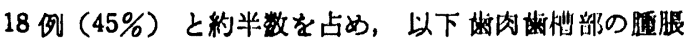

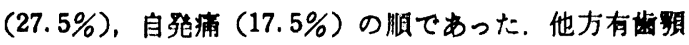
部や境界部のものでは齔の掘が12例 (41.4\%) と取も 多く，以下齿肉齿楷部の腯服 $(27.6 \%)$ ，齿痛，自発痛 の順で，因速する症状を初発症状としたものが16例 （55.2\%）と過半数を占めていた。 なお 3 例では影下な いし頸部リンパ節の腫大が初発症状であった。

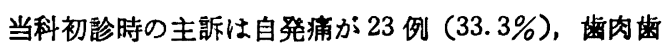
槽部の尰脹が21例 (30.4\%) と多く，以下顔面・下影部 の腫脹，接触痛・圧痛，齿の動搂，潧疡形成などの順 で, 初発症状に比べて自発痛中顔面・下䝷部の腫脹が增

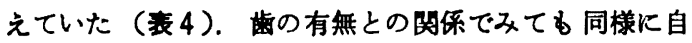
発痛と腫腿とが多かったが，有齿額部のものでは 5 例 (27.8\%)が觜痛や崡の動播など雪に関連する症状を主訴

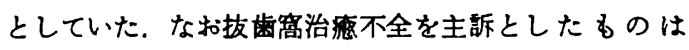
3 例であったが, 治庱不全症状は 6 例に認められた。

\section{4. 初診医㾴機威ならびに受診までの期間}

症状を自覚してから医䖒機网を受診するまでの期間は 表 5 のごとくで，60例（87\%）と大多数のものは症状自 覚後 3 か月以内に受診していた。 とくに35例と半数は症 状自筧後 1 か月以内之比較的早期に受郃していたか，他 方 6 か月以上放固していたものも数例みられた，初診医 療機関としては開業齿科か49例 (71.1\%) と王倒的に多 く, 直接当科を受診したものが 5 例，外科 4 例，内科 8 例，耳咽喉科 3 例であった。

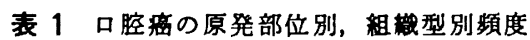

\begin{tabular}{|c|c|c|c|c|c|}
\hline 原発 部位 & 症例数（頻度） & 扁平上皮瘦 & その他の癌腫 & 肉 & 恶性黒色腫 \\
\hline 舌 & $91(30.2 \%)$ & 90 & 1 & 0 & 0 \\
\hline 口 腔 底 & $40(13.3 \%)$ & 34 & 6 & 0 & 0 \\
\hline 上頻歯肉 & $36(12.0 \%)$ & 28 & 3 & 3 & 2 \\
\hline 下願歯肉 & $74(24.6 \%)$ & 69 & 2 & 3 & 0 \\
\hline 煩 粘 膜 & $17(5.6 \%)$ & 17 & 0 & 0 & 0 \\
\hline 硬 口 蓋 & $20(6.6 \%)$ & 4 & 8 & 2 & 6 \\
\hline 口唇 & $7(2.3 \%)$ & 7 & 0 & 0 & 0 \\
\hline 頻骨中心性 & $16(5.3 \%)$ & 6 & 2 & 8 & 0 \\
\hline 計 & 301 & 255 & 22 & 16 & 8 \\
\hline （頻 度） & & $(84.7 \%)$ & $(7.3 \%)$ & $(5.3 \%)$ & $(2.7 \%)$ \\
\hline
\end{tabular}

注）日後部原発の 4 例は下䫟歯肉に含めた 


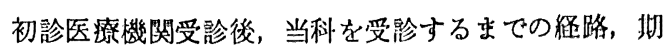
間をみると，直接当科を紹介されたものが32例，他の医 療機関を経由して当科に紹介されたものが27例で，後者 のちち10例は 3 つ上上の医療機関を受能していた。当科 に紹介されるまでの划間は，2週間以内か;32例，1か月 以内が14例之，70\%以上は比校的早期に紹介されていた が，3か月以上経過後に 紹介されたものも 11 例 (17.2

表 2 性则・作粭则頻度

\begin{tabular}{c|c|c|c}
\hline 年亚 & 塄 & 女 & 非 (\%) \\
\hline $20 \sim 29$ & 1 & & $1(1.5 \%)$ \\
$30 \sim 39$ & & & \\
$40 \sim 49$ & 2 & 1 & $3(4.3 \%)$ \\
$50 \sim 59$ & 13 & 3 & $16(23.2 \%)$ \\
$60 \sim 69$ & 20 & 8 & $28(40.6 \%)$ \\
$70 \sim 79$ & 13 & 3 & $16(23.2 \%)$ \\
$80 \sim$ & 1 & 4 & $5(7.2 \%)$ \\
\hline 計 & 50 & 19 & 69 \\
\hline
\end{tabular}

表了初発症状

\begin{tabular}{|c|c|c|c|c|}
\hline 症 例 数 & $\begin{array}{l}\text { 無曾 } \\
\text { 顎部 }\end{array}$ & $\begin{array}{l}\text { 境界 } \\
\text { 部 }\end{array}$ & $\begin{array}{l}\text { 有際 } \\
\text { 顎部 }\end{array}$ & 計 $(\%)$ \\
\hline 初 発症 状 & 40 & 11 & 18 & 69 \\
\hline 自発痛 & 7 & 1 & 2 & $10(14.5 \%)$ \\
\hline 接触痛 & 2 & & & 2 \\
\hline 口内異和感 & 2 & & 2 & $4(5.8 \%)$ \\
\hline 義歯不適合・疼痛 & 18 & 1 & & $19(27.5 \%)$ \\
\hline 歯肉歯槽部の腫脹 & 11 & 2 & 6 & $19(27.5 \%)$ \\
\hline 潰 湯 & 1 & & & 1 \\
\hline 白 斑 & 2 & & & 2 \\
\hline 畨 痛 & & 2 & 2 & $4(5.8 \%)$ \\
\hline 歯の動摇 & & 5 & 7 & $12(17.8 \%)$ \\
\hline 顔面・下顎部の腫脹 & & & 1 & 1 \\
\hline 顎下・頸部腫瘤 & 1 & 1 & 1 & 3 \\
\hline
\end{tabular}

\%)あり，とくに2つ以上の医療機関を経由しているも のにこの做问がみられた。な招，5侧は初影医療機関で の治療中に自意にて当科を受剈していた（表6）.

当科受部前に受けていた治療内容と期間は，口腔内洗 消ないし消炎が46例と最む多く，このうち42例は 1 か月 以内に当科を紹介されていた，抜蔽や切開を受けたもの

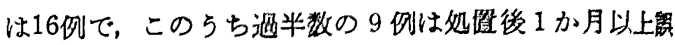

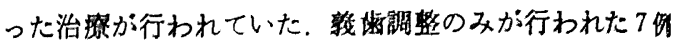
中 6 例は 1 か月以上経遄镭察が行われ，このうち2 例住 自意にて当科を受跈していた（表7）.

\section{5. 発生部位およひ场との関係}

発生部位は肉腿所見，X線所見，現病捱なとから推定

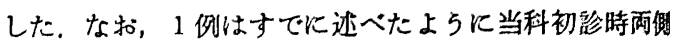

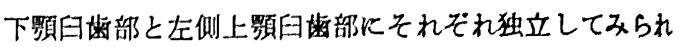
たため，则の胛瘍として报った。したがって㭘討奶象と

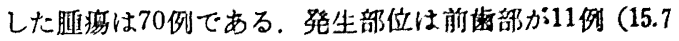

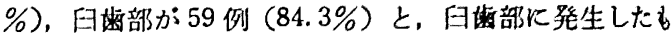
表 4 主跃

\begin{tabular}{|c|c|c|c|c|}
\hline 症 例 数 & 無蔽 & $\begin{array}{l}\text { 境界 } \\
\text { 部 }\end{array}$ & $\begin{array}{l}\text { 有歯 } \\
\text { 旗部 }\end{array}$ & 計 (\%) \\
\hline 訴 & 40 & 11 & 18 & 69 \\
\hline 自発痛 & 14 & 1 & 8 & $23(33.3 \%)$ \\
\hline 接触痛・圧痛 & 5 & 1 & & $6(8.7 \%)$ \\
\hline 口内異和感 & 3 & & & 3 \\
\hline 義稳不適合・疼痛 & 2 & & & 2 \\
\hline 㴹肉料槽部の畽眼 & 13 & 3 & 5 & $21(30.4 \%)$ \\
\hline 溞 瘍 & 2 & & 2 & $4(5.8 \%)$ \\
\hline 白 斑 & 1 & & & 1 \\
\hline 读 痛 & & & 1 & 1 \\
\hline 米の動摇 & & & 4 & $4(5.8 \%)$ \\
\hline 拔歯後治㾏不全 & & 2 & 1 & 3 \\
\hline 顔面・下䪽部の腫䐚 & 4 & 3 & 2 & $9(13.0 \%)$ \\
\hline 開口障害 & 2 & & & 2 \\
\hline 知覚麻瘒 & & & 1 & 1 \\
\hline 顎下・頟部腫瘤 & & 1 & & 1 \\
\hline
\end{tabular}

表 5 初診医療機関と受診までの期間

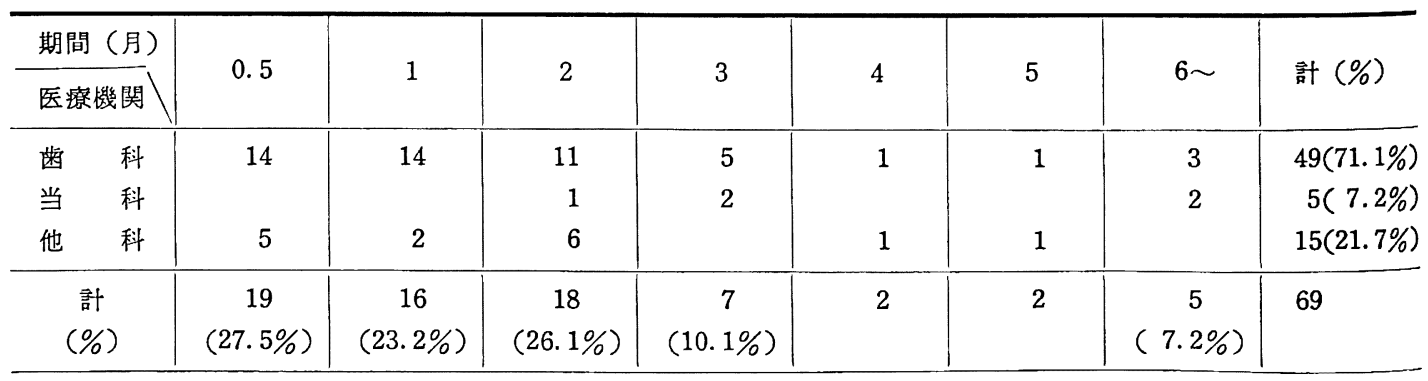




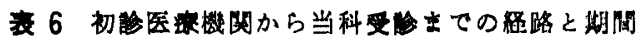

\begin{tabular}{|c|c|c|c|c|c|c|}
\hline 期間（月） & \multirow{2}{*}{0.5} & \multirow{2}{*}{1} & \multirow{2}{*}{2} & \multirow{2}{*}{3} & \multirow{2}{*}{$4 \sim$} & \multirow{2}{*}{ 垶 (\%) } \\
\hline 経路 & & & & & & \\
\hline 科 & 20 & 5 & 3 & & & $28(43.8 \%)$ \\
\hline 科 & 3 & 1 & & & & $4(6.3 \%)$ \\
\hline 米科与他科 & 8 & 6 & 3 & 3 & 7 & $27(42.2 \%)$ \\
\hline 自＼cjkstart意** & 1 & 2 & 1 & 1 & & $5(7.7 \%)$ \\
\hline $\begin{array}{l}\text { 計 } \\
(\%)\end{array}$ & $\begin{array}{c}32 \\
(50 \%)\end{array}$ & $\begin{array}{c}14 \\
(21.9 \%)\end{array}$ & $\begin{array}{c}7 \\
(10.7 \%)\end{array}$ & $\begin{array}{c}4 \\
(6.3 \%)\end{array}$ & $\begin{array}{c}7 \\
(10.9 \%)\end{array}$ & $64^{*}$ \\
\hline
\end{tabular}

注）*：直接当科を受診した 5 例を除く

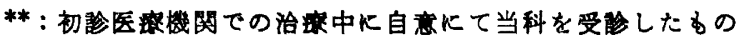

表 7 当科受診前の治港内容と期阔

\begin{tabular}{|c|c|c|c|c|c|c|c|}
\hline 冾塂期間（月） & \multicolumn{3}{|c|}{ 菌 } & \multicolumn{3}{|c|}{ 他 科 } & \multirow{2}{*}{ 計 } \\
\hline 治療内容 & $\sim 0.5$ & $0.5 \sim 1$ & $1 \sim$ & $\sim 0.5$ & $0.5 \sim 1$ & $1 \sim$ & \\
\hline 洗 & 16 & 2 & 1 & 3 & & 1 & 23 \\
\hline 消 & 5 & 3 & & 2 & 1 & 2 & 13 \\
\hline 拔歯・蛋爬 & 4 & & 7 & & & & 11 \\
\hline 切開 - 消炎 & 1 & 1 & & & 1 & 2 & 5 \\
\hline 試殹切除 & & & & 1 & 1 & & 2 \\
\hline 齿牙処置 & 1 & 2 & & & & & 3 \\
\hline 義歯調整 & & 1 & 6 & & & & 7 \\
\hline
\end{tabular}

表 8 発生部位

\begin{tabular}{c|c|c|c|c|c|c|c|c|c|c}
\hline RM & M & M PM & PM & I & 正中 & I & PM & PM M & M & RM \\
\hline 1 & 24 & 4 & 7 & 4 & 3 & 4 & 3 & 2 & 15 & 3 \\
\hline 1 & $35(50 \%)$ & & $11(15.7 \%)$ & $20(28.6 \%)$ & 3 \\
\hline
\end{tabular}

注） 1 例は 2 病巣のため計70例

のが大多数を占めていた。 とくに大田部が多く, 全体 の61.4\%を占めていた（表 8 ）.

雪との関係をみると，有歯影部のものが16例，無茵影

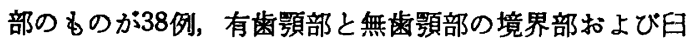
後部のものが15例と, 過半数は無菌䫝部に生じたもので

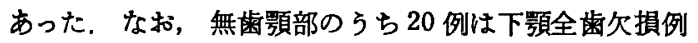
で，18例は部分的な歯牙欠損例であった。

\section{6. 腫湯の拡がり}

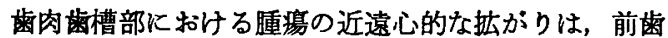
部に限局していたすの 4 例, 大曰歯部に限局していたも の 9 例, 日後部に限局していたもの 3 例で，残りの54例 （77.1\%）は初診時すでに他部位へ拡がっていた。 この らち両側に及んでいたものは正中部に生じたと考えられ
た 3 例を含めて15例 (21.4\%) であった，一方臨床症状

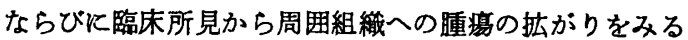
と, 表 9 のごとくで，歯肉歯槽部に限局していると診断 されたものはわずか21例（30\%）に過ぎなかった。

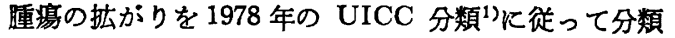
すると，原発腫湯では Tis および $\mathrm{T} 1$ 症例はなく， T2 症例 : 27 例, $\mathrm{T} 3$ 症例 : 6 例, $\mathrm{T} 4$ 症例 : 36 例之, 過半 数が $\mathrm{T} 4$ 症例であった. 所属りンパ節転移は $\mathrm{N} 0$ 症例 : 39 例, $\mathrm{N} 1$ 症例 : 28 例, N2 症例： 2 例で, $43.5 \%$ の症 例は初診時すでKリンバ節転移を伴っていた（表 10). 転移リンバ節の数は単発性のものが18例，多発性のもの が N2 症例を含め12例であった，転移部位は顎下リンパ 節34例, 上深顕リンパ節 2 例, 中深頸リンパ節 8 例で, 
UICC の賢部リンパ節枟移の レペル 分烦ではレベル 1 のもの 21 例，レペル 2 のの 9 例であった（图1），枟 移リンパ節の大きさは長径 $1 \mathrm{~cm} \sim 6 \mathrm{~cm}$ で，可效性は やや制限のあるものはみられたか，周围組織と明らかに 参首しているすのはなかった。なお，リンパ節枟移の有

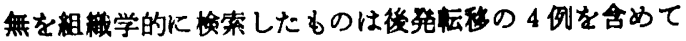

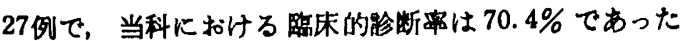
（变11）病期分類では St. II : 21例, St. III : 11例, St. IV : 37例と，全体の約70\%は進行例であった。

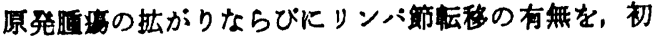
発症状自筧後当科来院までの期间でみると，T2・T3

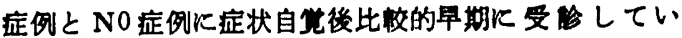
ろすのが多い佰向がみられたが，受䊽までの平均期间は $\mathrm{T} 2$ 症例 : 3.6 的, $\mathrm{T} 3$ 症例 : 3.8 的, $\mathrm{T} 4$ 症例 : 3.4

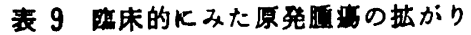

\begin{tabular}{|c|c|}
\hline 臨床敩状・所見 & 症 侧数 $(\%)$ \\
\hline 赖肉粕槽部に限局 & $21(30.0 \%)$ \\
\hline 煩粘膜浸滥 & $31(44.4 \%)$ \\
\hline 口腔底浸潤 & $18(25.7 \%)$ \\
\hline 臼後部浸洞 & $22(31.4 \%)$ \\
\hline 顔面・下颖部の尰腿 & $23(32.9 \%)$ \\
\hline 皮庙浸潤 & $4(5.7 \%)$ \\
\hline 開口幛害 & $17(24.3 \%)$ \\
\hline 舌運動陣害 & $1(1.4 \%)$ \\
\hline 知覚異常 & $14(20.0 \%)$ \\
\hline
\end{tabular}

表 10 TNM 分類

\begin{tabular}{|c|c|c|c|c|}
\hline $\mathbf{N}$ & 2 & 3 & 4 & 計 \\
\hline 0 & 21 & 4 & 14 & 39 \\
\hline 1 & 5 & 2 & 21 & 28 \\
\hline 2 & 1 & 0 & 1 & 2 \\
\hline 計 & 27 & 6 & 36 & 69 \\
\hline
\end{tabular}

注） T4N0の 1 例のみ M1，他は全例 M0

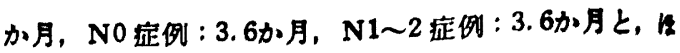
とんど窇は慨められなかった（衣 12）。

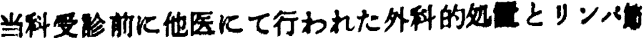

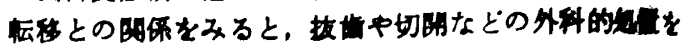
妾けていたるのでは18例中13例に忶秘がみられた。 たた

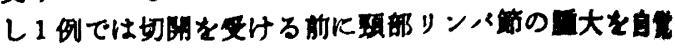

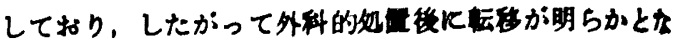
ったものは17例中12例 (70.6\%) でっった，一方外的

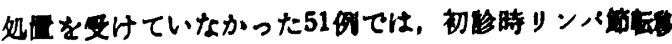

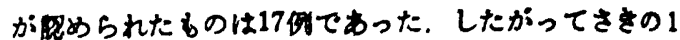

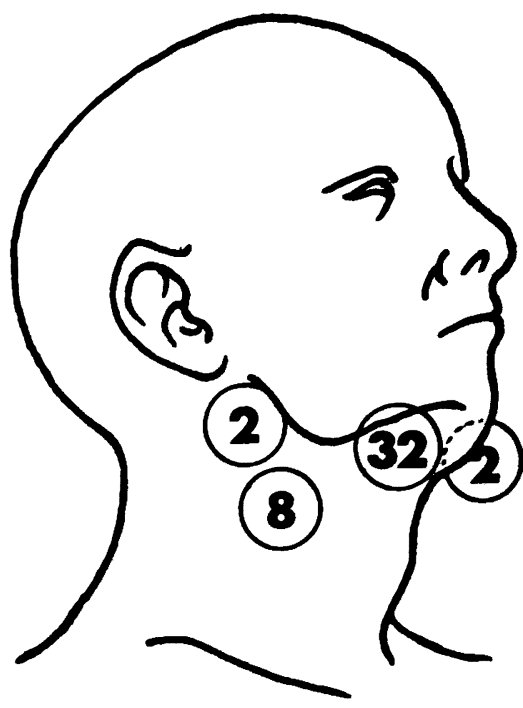

因 1 初馀時のリンパ笛坛移部立

表 $11 \mathrm{~N}$ と $\mathrm{pN}$ との比效

\begin{tabular}{c|c|c}
\hline $\mathrm{N}$ & $\mathrm{pN}$ & 㱏 \\
\hline+ & + & $14(51.9 \%)$ \\
+ & - & $7(25.9 \%)$ \\
- & + & $1(3.7 \%)$ \\
- & - & $5(18.5 \%)$
\end{tabular}

表 12 初発から当科受診までの期間と TN

\begin{tabular}{c|c|c|c|c|c|c|c|c}
\hline 期間 (月) & 0.5 & 1 & 2 & 3 & 4 & 5 & $6 \sim$ & 平均月数 \\
\hline $\mathrm{T} \cdot \mathrm{N}$ & & & & & & \\
\hline $\mathrm{T} 2$ & 2 & 3 & 4 & 9 & 4 & 1 & 4 & 3.6 \\
$\mathrm{~T} 3$ & & 2 & & 1 & & 1 & 2 & 3.8 \\
$\mathrm{~T} 4$ & & & 12 & 6 & 2 & 2 & 9 & 3.4 \\
\hline $\mathrm{N} 0$ & 2 & 7 & 6 & 9 & 4 & 3 & 8 & 3.6 \\
$\mathrm{~N} 1 \sim 2$ & & 3 & 10 & 7 & 2 & 1 & 7 & 3.6 \\
\hline
\end{tabular}


例を含め，52例中18例 (34.6\%) は外科的処畐とは成係 なく枟移を生じたるのと考えられた（品 13）.

初晾時に薏隔枟移が明らかであったすのは胸部X線像 で多発性の肺枟移が琶められた T 4N0M1 症例の 1 例の みであった。

\section{7. 内眼的所見}

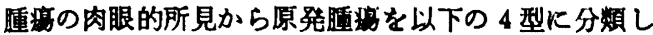
た．白斑型：婹疸が表在性で，白板症滕变化を主体とす

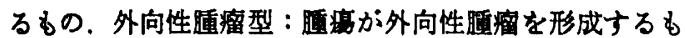
ので，盾溜の表面は釈頇状，肉芽状，verrucous 棣ある

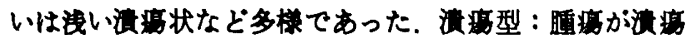
性変化を主体とするすので，その多くは周囲に堤防状隆

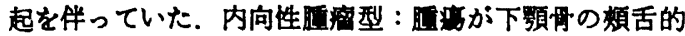

表 13 当科受診前に受けた外科的処腽と $\mathbf{N}$

\begin{tabular}{|c|c|c|}
\hline 外科的処㯰 & 症 例 数 & $\mathrm{N} 1 \sim 2$ \\
\hline 拔 㧘 & 8 & 6 \\
\hline 抜歯一捉爬 & 3 & 2 \\
\hline 切開- 試臾切除 & 7 & $5^{*}$ \\
\hline なし & 51 & 17 \\
\hline
\end{tabular}

注) *：1例は切開前に転移あり

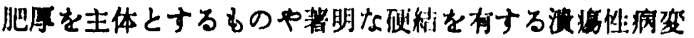
を量するもの，70 例中，白汸型はわずか 2 例で，外向

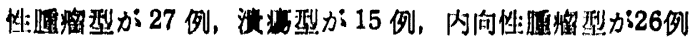

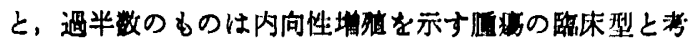

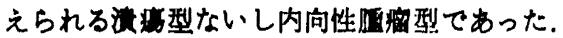

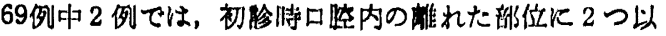

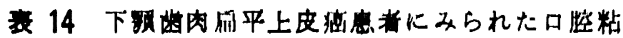

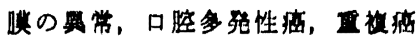

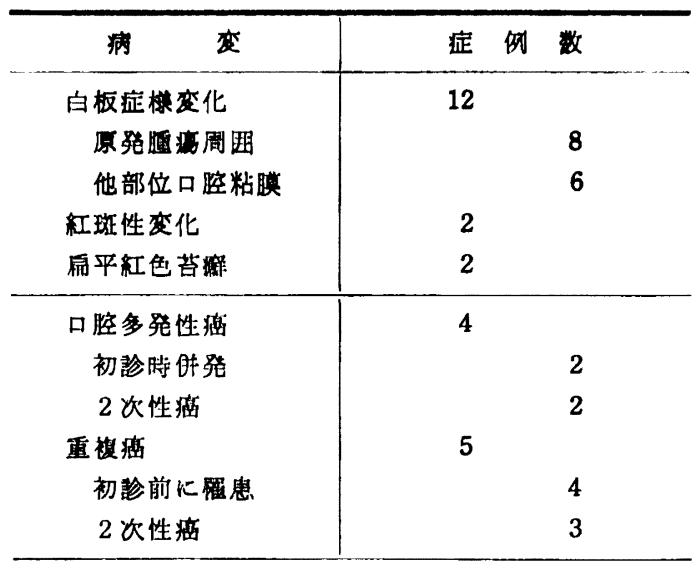

表 15 下影骨の吸収範囲と吸収様式

\begin{tabular}{|c|c|c|c|c|}
\hline$\frac{\text { 吸収籍囲 }}{\text { 吸収様式 }}$ & 下額骨上 $1 / 3$ & 下䫁骨中 $1 / 3$ & 下䫑骨下 $1 / 3$ & 計 \\
\hline $\begin{array}{l}\text { 骨吸収なし } \\
\text { Erosive } \\
\text { Invasive } \\
\text { 不 明 }\end{array}$ & $\begin{array}{l}20 \\
10\end{array}$ & $\begin{array}{l}5^{*} \\
7^{*}\end{array}$ & 12 & $\begin{array}{r}14(20.3 \%) \\
25(36.2 \%) \\
29(42.0 \%) \\
1(1.5 \%)\end{array}$ \\
\hline 計 & $30(55.6 \%)$ & $12(22.2 \%)$ & $12(22.2 \%)$ & $54-69$ \\
\hline
\end{tabular}

注)*: 5 例中 1 例， 7 例中 3 例では下䫟管浸潤が筑われた

有歯顥部

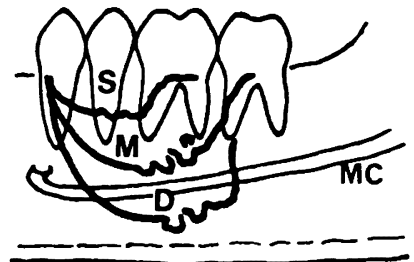

無歯影部

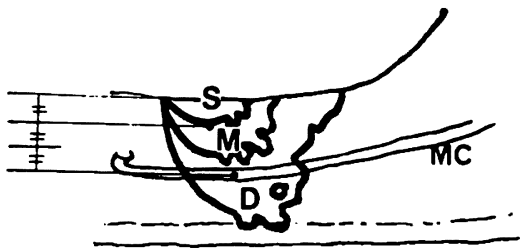

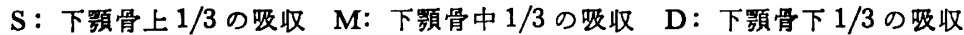
(MC：下額管)

图 2 下額骨の吸収範囲 


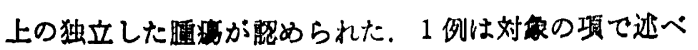
たすので，他の 1 例は左側下䫑臼齿部と硬口蓝部之に䏦

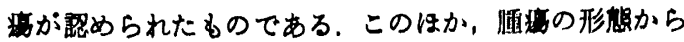
2つ以上の隀晹が互いに鳋合したと考えられたものが 2

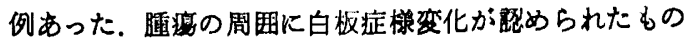
は白斑型の 2 例を含めて 8 例で，このらち 2 例では他部 位の口貯粘膜にも白板症棣变化がみられた。他部位の口 腔粘膜にのみ白板症様変化が認められたものは 4 例で， このほか扁平紅色苔㺕が 2 例に，紅斑性变化が 2 例に照 められた（表 14）.

\section{8. $\mathbf{x}$ 線所見}

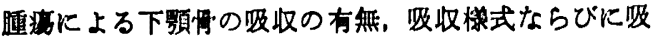
收籍围は衰15のごとくで，54例（78.2\%）に下顆悄の吸

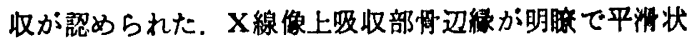
を呈する erosive type が 25 例，四収部解辺縓が不明瞅 で，不整形や蜂简状，虫哈状を呈する invasive type か: 29例であった。

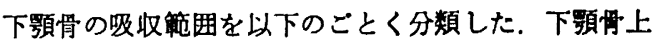

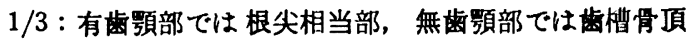
と下䫑管との厚さの蔽㡟骨頂側 $1 / 3$ 部までの吸収. 下䫑 骨中 $1 / 3:$ 下類骨上 $1 / 3$ を越之，下影管の走行に相当す る深さまでの吸収. 下䫑骨下 $1 / 3$ ：下頻管の走行に相当 する部よりる深部に達する吸収（図2）. 吸収の認めら れた 54 例中過半数の 30 例では吸収䇢囲は下影骨上 $1 / 3$ に 限局していたが，下䫑骨中 $1 / 3$ の 4 例を含め 16 例では下 額管への浸潤が簃われた。吸収様式と吸収範囲の関係を みると, erosive type のものでは $80 \%$ 以上が 下顥骨上 $1 / 3$ に限局していたが, invasive type のものでは下顆骨 上 $1 / 3$ に限局していたものは $34.5 \% て ゙, 51.7 \%$ と過半数 に下䪽管への浸潤が㱩われた。

初診から退院までの期間に 2 回以上X線撮影を行い, 下類骨の経時的な变化を比較しえた症例は 28 例であっ た. その結果は表16のごとくで，吸収籁囲が拡大したも のが19例，吸収範囲に変化のみられなかったものが 9 例 であった，観察期間を1か月て区切ってみると，1か月 以内に吸収範囲が払大したものが11例，1か月以上経過 後す吸収範囲に変化の認められなかったものが 7 例であ

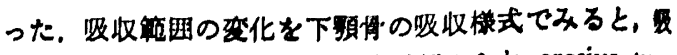
収栚式の速いにより明らかな整が琶められ, erosive type

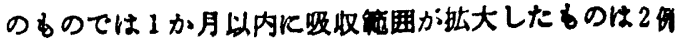

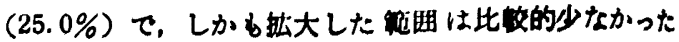
が invasive type のbのでは抁大は 9 侧 $(90.0 \%) \mathrm{K}$

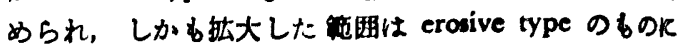

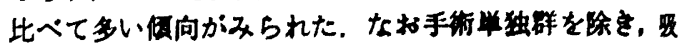

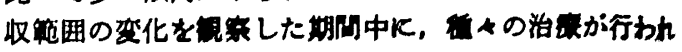
ていたが，治率の有無と吸収笛国の变化との间飞明らか な的俰は眼められなかった。

\section{9. 治港法}

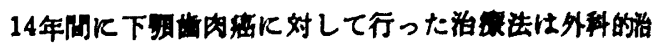

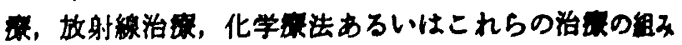

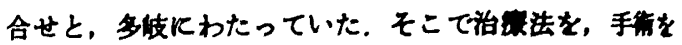
行った手術侀用群と手術を行かなかった手街非併用静と に大别し，以下の能时を行った。

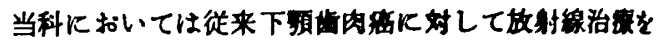
主体とする治率を行ってきたか，昭和51年10月以降，尚

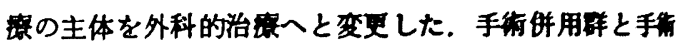
非併用群との比は全期间でるると46：23であるか，略和 51年10月以降（後期）で㤌 $34: 9$ と，手街を行った6の が增加している.なお後期の手術非併用群 9 例中 6 件怡 全身状態や年蛅から手術を行えなかったるので，他の3 例は手術を拒否したるのであった。

手術併用群：手術併用群における治度法の内訳は外科

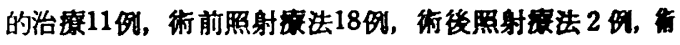

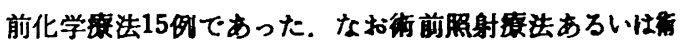

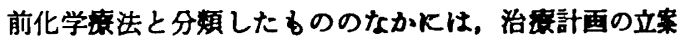
時から手術を予定していたるののはか，放射腺治震かい

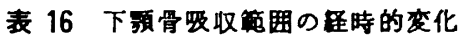

\begin{tabular}{|c|c|c|c|c|}
\hline \multirow{2}{*}{$\begin{array}{l}\text { 経時的変化・期 } \\
\text { 間 } \\
\text { 下預骨吸収畨式 }\end{array}$} & \multicolumn{2}{|c|}{ 変化なし } & \multicolumn{2}{|c|}{$\begin{array}{l}\text { 吸叹籍囲の䒧 } \\
\text { 大 }\end{array}$} \\
\hline & $0 \sim 4 W$ & $4 \sim 12 W$ & $0 \sim 4 W$ & $4 \sim 12 W$ \\
\hline Erosive & & 6 & 2 & 2 \\
\hline Invasive & 2 & 1 & 9 & 6 \\
\hline
\end{tabular}

表 17 洽餈法別の下額骨切除法, 项部部清法

\begin{tabular}{|c|c|c|c|c|c|c|c|}
\hline \multirow{2}{*}{ 治 鍙 法 } & \multirow{2}{*}{ 症 例 数 } & \multicolumn{3}{|c|}{ 下顎骨切除法 } & \multicolumn{3}{|c|}{ 顆部郭清法 } \\
\hline & & Marg. & Segm. & Hemi. & RND & UND & RND+UND \\
\hline 手＼cjkstart術 & 11 & 5 & 2 & 4 & 5 & & \\
\hline 㣨前昭射 & $18^{*}$ & 4 & 5 & 7 & 7 & 2 & 1 \\
\hline 犹後炤射 & 2 & 1 & & 1 & 1 & & \\
\hline 術前化学療法 & $15^{*}$ & 9 & 3 & 2 & 4 & & 1 \\
\hline 計 & 46 & 19 & 10 & 14 & 17 & 2 & 2 \\
\hline
\end{tabular}

注）*: 18 例中 2 例，15例中 1 例は腫晹切除のみ 


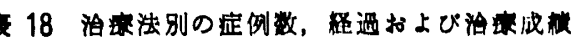

\begin{tabular}{|c|c|c|c|c|c|c|c|c|c|c|c|c|c|c|}
\hline \multirow{2}{*}{ 治 旅 } & \multirow{2}{*}{$\begin{array}{l}\text { 症例 } \\
\text { 数* }\end{array}$} & \multicolumn{3}{|c|}{ 病期 } & \multicolumn{2}{|c|}{1 次奻果 } & \multicolumn{3}{|c|}{ 跬 過 } & \multicolumn{3}{|c|}{ 治綃果 } & \multirow{2}{*}{3 年粗生存啝 } & \multirow{2}{*}{ 等攸正生存 } \\
\hline & & II & II & IV & 消失 & 存 & 再発 & $\mathbf{N} 0 \rightarrow$ & $\mid \mathrm{M} 0 \rightarrow$ & 生有 & 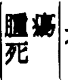 & 不明 & & \\
\hline 手 㣦 & 7 & 3 & & 4 & 7 & & 3 & 1 & & 6 & 1 & & & \\
\hline 政前炤射 & 15 & 5 & 4 & 6 & 14 & 1 & 2 & 1 & & 12 & 1 & 2 & $0 \%)$ & $3(92.3 \%)$ \\
\hline 很後昭射 & 2 & & & 2 & 2 & & $2 * *$ & & & & 2 & & $0 / 2$ & $0 / 2$ \\
\hline 微前化学法 & 8 & 4 & 1 & 3 & 8 & & 1 & 1 & & 6 & 2 & & $6 / 8(75.0 \%)$ & $6 / 8(75.0 \%)$ \\
\hline 小 & 32 & 12 & 5 & 15 & 31 & 1 & 8 & 3 & & 24 & 6 & 2 & $24 / 32(75.0 \%)$ & $24 / 30(80.0 \%)$ \\
\hline $\begin{array}{l}\text { 照 射 } \\
\text { 照射・化学法 } \\
\text { 化学埭法 }\end{array}$ & \begin{tabular}{c|}
$15(4)$ \\
$2(1)$ \\
2
\end{tabular} & 1 & 5 & $\begin{array}{l}9 \\
2\end{array}$ & 2 & $\begin{array}{r}10 \\
2\end{array}$ & 3 & 1 & 3 & 1 & $\begin{array}{r}12 \\
2\end{array}$ & 1 & $\begin{array}{l}3 / 15(20.0 \%) \\
0 / 2 \\
1 / 2(50.0 \%)\end{array}$ & $\begin{array}{l}3 / 11(27.3 \%) \\
0 / 1 \\
1 / 1(100 \%)\end{array}$ \\
\hline 計 & $19(5)$ & 3 & 5 & 11 & 7 & 12 & 3 & 1 & 3 & 4 & 14 & 1 & $4 / 19(21.1 \%)$ & $4 / 13(30.8 \%)$ \\
\hline 計 & 51 & 15 & 10 & 26 & 38 & 13 & 11 & 4 & 3 & 28 & 20 & 3 & $28 / 51(54.9 \%)$ & $28 / 43(65.1 \%)$ \\
\hline
\end{tabular}

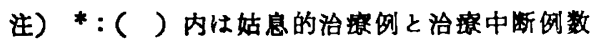
**：1例は颙部尰激のみの再発

し化学療法を施行中あるいは施行後に期待していた治療 効果が得られず，手術を行ったものす数例含まれてい る. 下頻骨切除法ならびに頚部郭清術の有無は表17のご とくで, 下颗骨辺緑切除術 19 例，下䫇骨連続離断術 10 例, 下頻骨半側切除術 14 例, 腫䔾切除術 (cryosurgery を含む） 3 例であった. 初回手術時同時に頚部郭清術を 行ったものは21例，23側で，郭清範囲は1側の全頸部郭 清が17例， 1 側の全顓部郭清と反対側の上頚部郭清が 2 例, 1 側の上頡部郭清が 2 例であった。なお21例中 7 例 はN0症例で，いわゆる予防的颛部郭清例であった。術 前照射群ならびに術後照射群における照射法はいずれ むCobalt-60 に上る外照射で, 腫煬線量は前者で 4,000 $\mathrm{rad} / 16 \mathrm{f} / 4 \mathrm{w}-6,500 \mathrm{rad} / 26 \mathrm{f} / 6.5 \mathrm{w}$, 後者 16f/4 w であった. 術前化学㙩法群に㧍ける使用薬郕と 投与法は，BLM 7 例 $(15 \mathrm{mg} \times 5$ 回 $15 \mathrm{mg} \times 20$ 回 $)$, Pepleomycin 2 例( $10 \mathrm{mg} \times 3$ 回 $10 \mathrm{mg} \times 12$ 回), MTXCF 6 例 $\left(50 \mathrm{mg} / \mathrm{m}^{2} \times 2\right.$ 回 $350 \mathrm{mg} / \mathrm{m}^{2} \times 2$ 回) であ った.

手術非併用群：手術を行わなかったすのは23例で,こ の5ち尰㷎の浸潤が広範囲に及び姑息的治療のみに終始 した 3 例と，治療中に全身状態が悪化し治療を中断した 3 例を除いた17例飞根治的治療が行われていた．根治的 照射群における照射法は Cobalt-60による外照射で, 照射線量は $5,500 \mathrm{rad} / 16 \mathrm{f} / 4 \mathrm{w}-6,500 \mathrm{rad} / 26 \mathrm{f} / 6.5 \mathrm{w}$ であった。根治的化学療法群における使用薬剂は BLM 2 例 $(15 \mathrm{mg} \times 20$ 回, $15 \mathrm{mg} \times 16$ 回) で，MTX を使用 した 1 例は白血球減少をきたしたため治療を中断した。 照射化学潦法群に淤る照射法, 使用薬剤は Cobalt-60 $(6,500 \mathrm{rad} / 26 \mathrm{f} / 6.5 \mathrm{w}), \mathrm{BLM}(15 \mathrm{mg} \times 14$ 回, $15 \mathrm{mg} \times$
20回）であった.

\section{0. 初回治㾧後の経過}

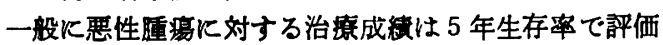
されている。しかし今回対象とした症例のなか沈治療 後 5 年を経過したすのは少なく，また口腔扁平上皮蝠に おいては再発や転移は治寮後 $1 \sim 2$ 年以内にみられるこ とが多く，3 年生存率と 5 年生存率との間に汪とんど差 が認められないことが知られている．そこで治境後の経 過や治療結果，治療成綪に関しては治寮後 3 年以上を経 過した51例を対象として検討した（表 18）.

51例中姑息的治療のみを行ったものが 3 例，治療を中 断したものが 2 例で，残りの 46 例に対して根治的治潦が 行われていた．初回治療により睡瘍が消失したるのは38 例で，このうち再発は11例にみられたが，再発としたも ののらち 2 例では再発腫瘍は原発腫瘍が存在した部位か $52 \mathrm{~cm}$ 以上離れた部位（1 例は同側上影臼部柴肉, 他の 1 例は同侧口蓋部) に認められており，口腔多発性 癌の可能性む否定しえなかった，初回治療後价所属リン 八節転移を生したものは 4 例で，このらち 2 例では原発 睡瘍に残存ないし再発がみられた。したがって根治的治 療例に対する 初回治療の腫湯制御率は $54.3 \%(25 / 46)$ となる．治療法別では手術併用群で $65.6 \%$, 手術非併用 群で28.6\%と，前者が数段勝っていた。

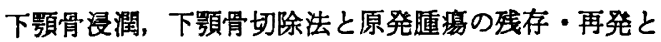
の関保は表 19 のごとくで，下䫑骨吸収様式と腫湯の线 存・再発との間に密接な関連がみられた。すなわちX線 所見で下䅡骨の吸収が明らかでないるのや erosive type の吸収を示するのでは, 腫場の残存・再発は15.0\%にみ られたのみであったが, invasive type の吸収を示した 


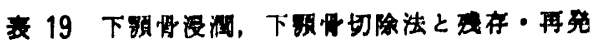

\begin{tabular}{|c|c|c|c|c|c|c|}
\hline \multicolumn{2}{|c|}{ 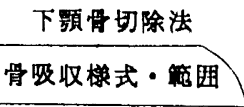 } & 望瘦切除 & Marg. & Segm. & Hemi. & if \\
\hline \multicolumn{2}{|c|}{ 骨吸収なし } & $0 / 2$ & $1 / 3^{B}$ & & $0 / 1$ & $1 / 6$ \\
\hline Erosive & $\begin{array}{l}\text { 上 } 1 / 3 \\
\text { 中 } 1 / 3 \\
\text { 下 } 1 / 3\end{array}$ & $1 / 1^{8}$ & $0 / 5$ & $\begin{array}{l}0 / 3 \\
0 / 2\end{array}$ & $\begin{array}{l}1 / 1^{8} \\
0 / 2\end{array}$ & $\begin{array}{l}2 / 10 \\
0 / 4\end{array}$ \\
\hline Invasive & $\begin{array}{l}\text { 上 } 1 / 3 \\
\text { 中 } 1 / 3 \\
\text { 下 } 1 / 3\end{array}$ & & $2 / 5^{\text {P.P. }}$ & & $\begin{array}{l}1 / 1^{p} \\
0 / 1 \\
2 / 58.8\end{array}$ & $\begin{array}{l}3 / 6 \\
0 / 1 \\
2 / 5\end{array}$ \\
\hline 計 & & $1 / 3$ & $3 / 13$ & $0 / 5$ & $4 / 11$ & $8 / 32$ \\
\hline
\end{tabular}

注）分母怔例数，分子は存・再発例数

Pは下预骨断端部ないし下颖骨周边部の再発を示し，

Sは下预骨から隔った粉組部の再発を示す

あのでは41.7\%にみられた，再発部位をみると，下預搰 断端部ないし下䂓骨周辺部にみられたすのが 3 例，下影

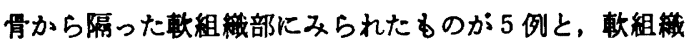
部に再発したものが多かった。 また下額骨吸収粎式との 関係をみると，下影骨断端部ないし下影骨周辺部に再発 がみられたものはいずれる invasive type の吸収を示し たものであった。

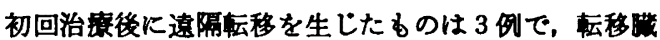

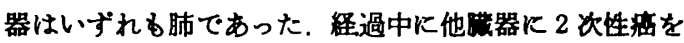
生じたものは 2 例で，1 例は喉頭癌，他の 1 例は下影骨 中心性瘦であった．後者は下影齿肉癌の再発ないし枟移 る否定しえないが，当科初診の約20年前に中咽頭瘇场に 対して放射線治㞠を受けていたことや，再発腫㾨は原発

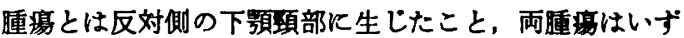
れも照射野内に発生していたことなどから，放射線照射 により誘発された重複癌症例と診断した。なおこの持 飞も, 治療後 3 年末満の症例のなか喉頭癌を生したす のが 1 例含まれている（表 14）.

初回治療により原発連場を制御しえなかった19例のら ち再治療が可能であった10例に 2 次治療を行った．治療 法恃外科的治療か; 7 例，放射線治㞠が 2 例，照射化学㞠 法が 1 例であった（表 20）。初回治㞠後にリンバ節枟移 を生じた 4 例中 2 例には全頱部郭清術を，他の 2 例には 放射線治療を行った。

\section{1. 治湶成維}

治療後 3 年を経過した時点での治療結果は，腫瘍なく 生存中のもの28例, 腫瘍死したもの20例, 追跡不能とな ったすの 3 例であった，追跡不能例のうち 1 例は治療後 2 年 8 か月, 他の 2 例は治療後 1 年の時点で, 尰瘍の再 発や転移は認められず生存中であったが，それ以降の追 跡が行えなかったものである。したがって当科における

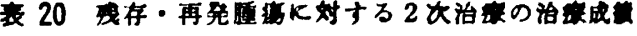

\begin{tabular}{|c|c|c|c|c|c|c|}
\hline \multirow{2}{*}{ 初回治都 } & \multicolumn{2}{|c|}{$\begin{array}{ll}2 & \text { 次 } \\
\text { 洽 }\end{array}$} & \multicolumn{3}{|c|}{ 治续期果 } & \multirow{2}{*}{ 生 存 } \\
\hline & 手龟 & その & 生存 & 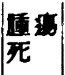 & 不明 & \\
\hline 手乪併用 & 6 & 2 & 4 & $\begin{array}{l}2 \\
2\end{array}$ & & $\begin{array}{l}4 / 6(66.7 \%) \\
0 / 2(0 \%)\end{array}$ \\
\hline 手征非併用 & 1 & 1 & 1 & 1 & & $\begin{array}{l}1 / 1(100 \%) \\
0 / 1(0 \%)\end{array}$ \\
\hline
\end{tabular}

下影齿肉扁平上皮舟 1 次伊の 3 年祖生存率は54.9\%(28/

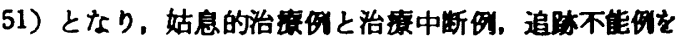
除いた 3 年修正生存率は65.1\%(28/43) となる（表18).

治㫫法別の生存率をみると手街を行ったもので成界が 良く, 手術併用群の 3 年相(正) 生存率は75.0\%(80.0 \%)であった．他方手術を行わなかったるのでは，化学

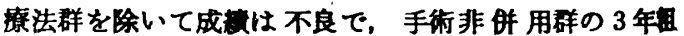
（正）生存率は $21.1 \%$ (30.8\%) であった. ただし病 期分布をみると，手術併用群比比でて手術非并用群では 進行例の占める割合が高かった。 そこで治愎法別，病期 別に生存率をみたのは表21である。これによれは治㫫成 镨は病期とよく相関し，St. II では 3 年正生存率が 91.7\%であるのに比べ， St. I，St. IVではそれぞれ70.0 $\% ， 47.6 \%$ と，病期が進む炕つれて著明に低下してい た。 また病期別にみても手術を行ったるので成䵊が良

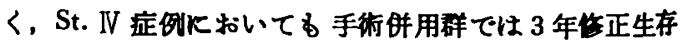
率は60.0\%であったか，手術非併用群ではわずか $16.7 \%$

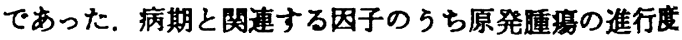
と治療成續との関俰（表 22）をみると， T4 症例がとく に不良で, T2, T3 症例の 3 年修正 生 存率か $80 \%$ 以上 


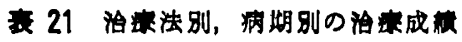

\begin{tabular}{|c|c|c|c|c|}
\hline 病期 & \multirow{2}{*}{ St. II } & \multirow{2}{*}{ St. III } & \multirow{2}{*}{ St. IV } & \multirow{2}{*}{ it } \\
\hline 治 法 & & & & \\
\hline 手综併用群 & $10 / 10$ & $5 / 5$ & $9 / 15$ & $24 / 30(80.0 \%)$ \\
\hline 手胙非併用群 & $1 / 2$ & $2 / 5$ & $1 / 6$ & $4 / 13(30.8 \%)$ \\
\hline 計 & $\begin{array}{c}11 / 12 \\
(91.7 \%)\end{array}$ & $\begin{array}{c}7 / 10 \\
(70.0 \%)\end{array}$ & $\begin{array}{c}10 / 21 \\
(47.6 \%)\end{array}$ & $28 / 43(65.1 \%)$ \\
\hline
\end{tabular}

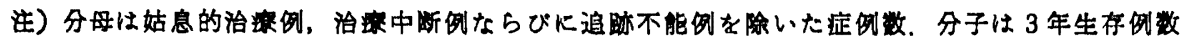

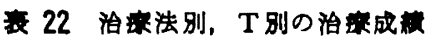

\begin{tabular}{|c|c|c|c|c|}
\hline 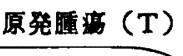 & \multirow{2}{*}{$\mathrm{T}^{2}$} & \multirow{2}{*}{ T3 } & \multirow{2}{*}{$\mathrm{T} 4$} & \multirow{2}{*}{ 計 } \\
\hline 治 法 & & & & \\
\hline 手综併用群 & $12 / 12$ & $3 / 3$ & $9 / 15$ & $24 / 30(80.0 \%)$ \\
\hline 手继非併用群 & $2 / 5$ & $2 / 3$ & $0 / 5$ & $4 / 13(30.8 \%)$ \\
\hline 計 & $\begin{array}{c}14 / 17 \\
(82.4 \%)\end{array}$ & $\begin{array}{c}5 / 6 \\
(83.3 \%)\end{array}$ & $\begin{array}{c}9 / 20 \\
(45.0 \%)\end{array}$ & $28 / 43(65.1 \%)$ \\
\hline
\end{tabular}

注）表21k同し

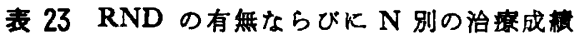

\begin{tabular}{c|c|c|c}
\hline N & N0 & N1 2 & 計 \\
\hline RND & & & \\
\hline なし & $14 / 18(77.8 \%)$ & $4 / 13(30.8 \%)$ & $18 / 31(58.1 \%)$ \\
あり & $4 / 4(100 \%)$ & $6 / 8(75.0 \%)$ & $10 / 12(83.3 \%)$ \\
\hline 計 & $18 / 22(81.8 \%)$ & $10 / 21(47.6 \%)$ & $28 / 43(65.1 \%)$ \\
\hline
\end{tabular}

注）表21 K同し

であったのに比へ，T4症例では 45.0\%であった。 また 治寮法に上り治療成績に差が みられ，手術併用群では $\mathrm{T} 2$ ・ T3 症例で $100 \%$ ，T4症例です60.0\%であった が，手術非併用群 では $\mathrm{T} 2$ 症例で $40.0 \% ， \mathrm{~T} 3$ 症例で $66.7 \%$ で， T4 症例では生存例は1 例もなかった. 次に リンバ節転移と治療成瞔との関係（表23）をみると，
$\mathrm{N} 0$ 症例の 3 年正生存率が $81.8 \%$ であったのК比ぺて $\mathrm{N} 1 \sim 2$ 症例では 47.6\%と， $N(+)$ 群の治㞠成就が明ら かに不良であった。枟移の有無を組繶学的に確認しえた ものではその差はさらK明らかで, $\mathrm{pN} 0$ 症例の 3 年修 正生存率が 87.5\%であったのに比ぺて pN 1 2 症例で は 42.9\%であった（表 24）。たたし顓部郭清術を行った すのでは成㛭は比較的良好で, N1〜2症例および $\mathrm{pN}$ 1〜2 应例の 3 年修正生存率はともと $75.0 \%$ ，頸部郭 清術を行わなかったN0症例の $77.8 \%$ と注注同様の成耫 であった。

珄，年齢と治療成䋶との夙係をみると，治療成績は病 期, 治療法とのみ闺連し, 年龄, 性との間には明らかな 関係は認められなかった。

下額齿肉扁平上皮癌化対する治寮法の主体を放射線治 療から外科的治療へと変更した昭和 51 年 10 月以前とそれ 以後の治療成積を比較したものが表25で，両者間で病期

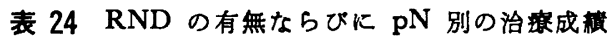

\begin{tabular}{|c|c|c|c|c|c|}
\hline$\frac{\mathrm{pN}}{\mathrm{RND}}$ & & $\mathrm{pN} 0$ & $\mathrm{pN} ?$ & $\mathrm{pN} 1 \sim 2$ & 計 \\
\hline $\begin{array}{l}\text { な } \\
\text { あ }\end{array}$ & $\begin{array}{l}\text { L } \\
b\end{array}$ & $7 / 8(87.5 \%)$ & $18 / 28(64.3 \%)$ & $\begin{array}{l}0 / 3(0 \%) \\
3 / 4(75.5 \%)\end{array}$ & $\begin{array}{l}18 / 31(58.1 \%) \\
10 / 12(83.3 \%)\end{array}$ \\
\hline 計 & & $7 / 8(87.5 \%)$ & $18 / 28(64.3 \%)$ & $3 / 7(42.9 \%)$ & $28 / 43(65.1 \%)$ \\
\hline
\end{tabular}

注)表21K同し 


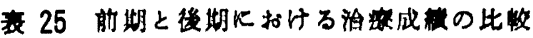

\begin{tabular}{|c|c|c|c|c|c|c|c|c|c|c|}
\hline \multirow[b]{2}{*}{ 胡 } & \multirow[b]{2}{*}{ 治 法 } & \multirow{2}{*}{$\begin{array}{l}\text { 症例 } \\
\text { 数 }\end{array}$} & \multicolumn{2}{|c|}{ 狃 } & 期 & \multicolumn{3}{|c|}{ 治綃果 } & \multirow{2}{*}{\multicolumn{2}{|c|}{3 年智生存率 }} \\
\hline & & & St. II & St. $\mathbb{I}$ & St. IV & 生存 & 盛要 & 不明 & & \\
\hline 1970. $1 \sim 1976.9$ & 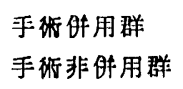 & $\begin{array}{l}12 \\
14\end{array}$ & 8 & 6 & 12 & $\begin{array}{l}6 \\
3\end{array}$ & $\begin{array}{r}5 \\
10\end{array}$ & $\begin{array}{l}1 \\
1\end{array}$ & $\begin{array}{l}6 / 12(50 \%) \\
3 / 14(21.4 \%)\end{array}$ & $9 / 26(34.6 \%)$ \\
\hline 1976. $10 \sim 1980.12$ & 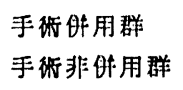 & $\begin{array}{r}20 \\
5\end{array}$ & 7 & 4 & 14 & $\begin{array}{r}18 \\
1\end{array}$ & $\begin{array}{l}1 \\
4\end{array}$ & 1 & $\begin{array}{c}18 / 20(90.0 \%) \\
1 / 5(20.0 \%)\end{array}$ & $19 / 25(76.0 \%)$ \\
\hline
\end{tabular}

には明らかな差はみられないか， 3 年粗生存躬は前期が

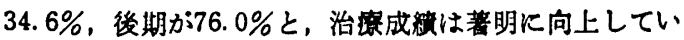

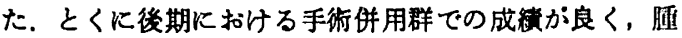
瘍死したものは20例中わずか1例であった.

初回治㞠後の残存・再発例に対する 2 次治療の結果は 表20のごとくで，手術を行ったものでは 7 例中 5 例を救 命しえたが，手術を行わなかったものでは全例が隀淘死 していた.

\section{考察}

\section{1. 下額菌肉扁平上皮素の病俧像について}

下頢齿肉癌の頻度は調查医瘄機関によりかなりのばら つきがみれるが，口腔癌の20〜30\%を占めると考えら れる 2 14)、組織型では扁平上皮癌が圧倒的に多く, 全体 の 80〜 90\%を占めている 肉癌は口腔癌 1 次症例の $24.6 \%$ を占め, そのうち $93.2 \%$ は扁平上皮癌であった。下影齿肉扁平上皮癌に拈ける男 女比は2.6:1で, 本邦における下䝷癌や下額齿肉癌の 性差に比べて男性により多く発生していた旦〜18). 初診時 の年龄は男女とも60歳代が最も多く，50歳以降のものが 全体の $94.2 \%$ を占めており，下影癌や下額崡肉癌におけ る年龄分布と同様の結果であった ${ }^{16 \sim 18)}$.

初発症状としては，義歯不適合や歯肉歯慒部の腫脹， 崡の動摇，疼痛など，歯や歯周組織の疾患の際にみられ る非特異的な症状が多く，このため70\%以上の患者は初 診医療機関として開業歯科医を受診していた。このこと は下䫑齿肉癌の早期発見といら点から，開業齿科医の果 たす役割がわわて大きいことを示している15,17,18). 初 発症状は尰湯が発生した部位における雪の有無によって

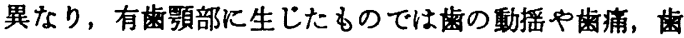
肉歯槽部の腫脹など，㐘に関連した症状を呈するものが 多かったが，無歯頡部に生じたものでは義崡不適合や疼 痛を初発症状としたものが多かった，従来から下影齿肉 癌においては腫脹や疼痛, 潰痬などが初発症状ないし主 訴として重要視されてきたか，義歯不適合に関しては Cady \& Catlin $^{15)}$, 手島 ${ }^{17)}$ の報告以外は記载されて いない。これは義崡不適合の訴えを腫脹や潰瘍, 疼痛な
どの唄に分類したためと考えられ，实际には第不道合 を主盺とするるのはかなり多いと思われる，症状自视後

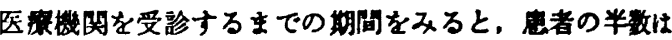
1 か月以内に，また約 $90 \%$ は 3 か月以内に受路してい

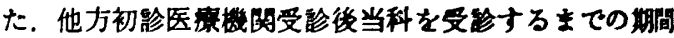

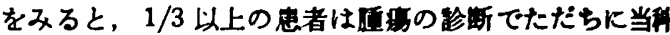
を稆介され，また70\%以上の息者は1 か月以内当科を 受診していたか，3か月以上释過後に骎领したいのが17

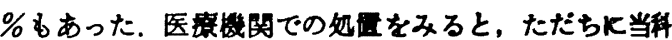
を稆介された23例を除き，大部分の患者が消奖露法中位 农，切開などを受けていた。これらの処青を受けた患者 の半数は 1 か月以内に当科入船介されていたか，成りの

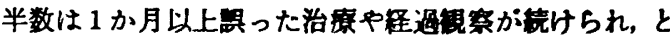

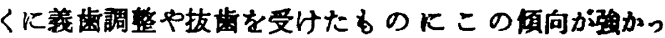

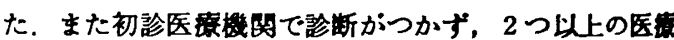
機関を受診していたるのが約 $40 \%$ るみられた。これらの

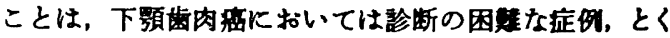
飞歯性炎症との別困趡な症例が少なからす存在するこ とを示するのと思われる15,17)。したがって下預画肉峦の

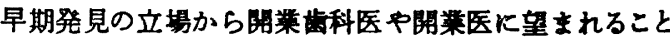
は，診断の明らかでない症例や通常の消奖療法原反応し ない腫脹や潰湯に远通した場合はただちに口腔外科など しかるべき施設へ患者を稆介することで，拔齿や切䦎な

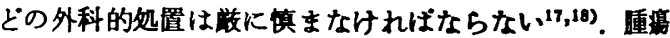

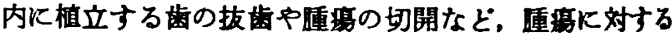
機械的な刺激は原発連漸を増大させ，枟移を促進させる ことが知られている ${ }^{15,19)}$. 今回の検討でる外科的処居を 受けていた群の初祅時転移陽性率は70.6\%と，外科的処 置を受けていなかった群の34.6\%に比べて 2 倍以上る高 かった．両群の差はただちに外科的処圈によるるのとは 断定しえないが，注目すべき結果であった．な招初発症 状自覚後当科を受診するまでの期間と，初診時に叔りる 原発尰湯の大きさならびに所属リンバ節枟移の有無との 間には明らかな関係はみられなかった。このことは，所 属リン八゙節の腫大が初発症状であった症例がみられたこ ととともに，下頻歯肉扁平上皮密には進行の早いものと 遅いものとがあることを示するのと考えられる.

発生部位は従来の報告 ${ }^{15}$ 18) と同様に日歯部が多く， 
なかでも大田部に生したすのが全体の61\%を占めてい た。一方，崡との凮係をみると無歯䫑部のすのが過半数

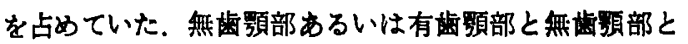
の境界に発生したものが多いことは，下䫓歯肉扁平上皮 癌の発生に関して義橧やクラスブなどが何らかの役揢を 果したことが想像されるが20 22)，義歯を全く使用して いなかった症例す数例あり、これらの点に関しては明ら かではなかっだフ

下頻踩肉癌においては初馀時すで進行例であるすの

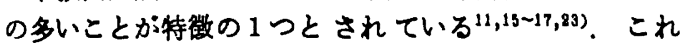
は歯肉槽部の解剖学的な特改のはか，すでに还べたよ らに初発症状下特巽的なるのがなく診断が幄れること

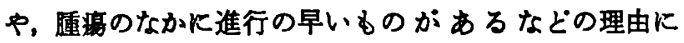
よるすのと思われる. 今回検討した 69 例においても， $\mathrm{T} 3 \sim 4$ 群: $60.9 \%, \mathrm{~N} 1 \sim 2$ 群 : $43.5 \%$, St. II $\sim \mathbb{V}$ 群 : $53.6 \%$ ，過半数が進行例であった，周囲組樴との関係 をみても，肉眼的に連湶が歯肉慒部に限局していたも のは30\%，X線所見で骨の吸収や破壊が明らかでなかっ たものは22\%と，大部分のるのでは初診時すでに周囲組 織へと浸潤していた。齿肉畨部に拁ける近遠心的な拡 がりをみてす，前崡部に発生したすのを含めて21.4\%の ものが正中を越えて両側性に払がっていた．また前㙁部 に尰場が存在ないし波及していたものが全体の $31.4 \%$ を 占めていた．これらのことは，約 $1 / 3$ の症例では両側性 転移の可能性があり，また下額骨連続離断など下影骨の 連続性を損ら手術を行った場合には高度の障害を残すこ とを意味し，下顮䨑肉癌に対する治療の困奞性を示して いる3 ${ }^{15,25)}$.

初診時にリンハ節転移が認められたすのは30例 (43.4 \%)であった.この数値は本邦における従来の報告 ${ }^{16,24,25)}$ に比へてて若干低率であるが，従来から下類歯肉癌では反 応性のリンバ節腫大を伴らことが多く，臨床的な転移陽 珄率と組織学的に確認された転移率との間にかなりの差 違のあることが指摘されている15,26)，当科における転移 リンパ節の臨床的診断率は70.4\%で，しかも誤診であっ た 8 例中 7 例は組織学的飞転移が認められない false positive 例であった。したがって実際の転移率は30\%前 後であろらと推定される。転移部位は両側性転移が疑わ れた 2 例を含めて全例がレベルII留っており，従来の 報告と一致していた ${ }^{15,26-28)}$.

X線所見で下額骨に変化が認められたるのは54例（78 \%)で，しかもそのらち約半数では骨の吸収や破壊は下 顎骨体部に及んでいた，従来から腫煌による下類骨の吸 収中破壊はX線所見により平滑状吸収 erosive type と 虫喰状吸收 invasive type とに分類され, 組織学的所見 との関連や治療法との関連において種々論議されてい $3^{20-811}$. 徒来の報告では下影歯肉癌においては invasive type を示するのが多いとされているが，今回検討した すのでは erosive type 25例, invasive type 29例とはぼ

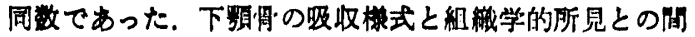

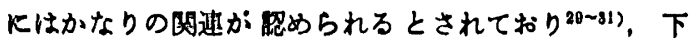

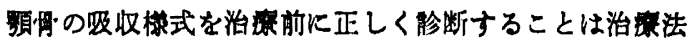
を決定するろえでわめて亚要である，しかしX線所見

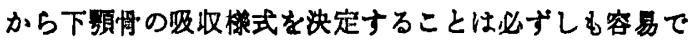
はなく，今回検钨した症例のなかにもいずれの type に 分類すべきか判定に苦減したものが少なからす存在し た，従来の報告をみても非興型的な吸収栐式を示す应例

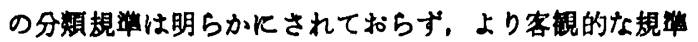
の確立されることが望まれる。なお，今回榆时した症例 において, invasive type のむのにおいては初刢から手

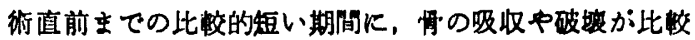
的急速に進行する佰向がみられたが，一方 erosive type のものにおいてはこれらの変化ははとんど㴶められなか った。これらの所見は下影䯚の吸収棣式を分類するらえ で1つの目安となると考えられるが，経時的变化を確認 しえた症例が少なく, 詳細に関しては改めて報告する予 定である.

近年口腔癌に批ける多発性癌や 2 次性癌が問題とされ ている ${ }^{11,15,32 \sim 34)}$. 今回娭討したもののなかにる口腔多 発性瘦と考えられたものが 4 例みられた。 2 例は初診時 下影歯肉癌以外に独立した尰晹がみられたるので，他の 2 例は下影齿肉癌の治療後に認められたため, 下額歯肉 癌の再発として报ったが，発生部位からみて多発性癌の 可能性が高いと考えられたものである。. また，この伍か

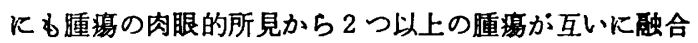
したと考えられるものが 2 例あった。，腔以外の眼器に 悪性腫瘍が認められたすのは 5 例で，このらち 3 例は三 重癌症例であった．したがって下影齿肉扁平上皮癌患者 の約10\%は口腔多発性癌症例や重複癌症例といらことに なる. また重複癌症例のらち 3 例は下罰齿肉癌の治療後 飞認められた。したがって下頢歯肉扁平上皮癌患者が 2 次性癌濰患する割合は $7.2 \%$ で，1 年以上再発なく生 存しているものでは約15\%となる。これらの数值は現時 点でも無視しえないすのであるが, 治窟率が向上し，ま た平均寿命が長くなるに従ってさらに增加するすのと思 われる.

2. 下頻崡肉扁平上皮愊の治療ならびに治療成績につ いて

下頻歯肉癌飞対する治療法は従来外科的治療と放射線 治療が主体であっだ,6,25,35). しかし放射線治㞠のみで は下䅡骨内へ浸潤した腫場を制御することが困奞なこ とや，放射線治療を行ったものでは治療後に重篤な骨 障害を生じることが少なくないことなどから，最近で は外科的治療を主体とするすのが主流となってきてい $3^{2,15 \sim 17,25,28)}$. 治療成績をみても, 放射線治療を主体之 したものでは 5 年生存率でみて30〜 40\%にとどまってい

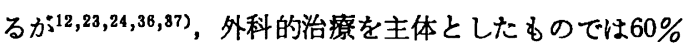
以上の成績も得られている ${ }^{28,38)}$. 当科においては從来放 


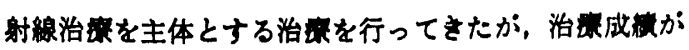
不良なことから，昭和51年10月以降は治主体を外科 的治翼へと变更した．その結果は表25のごとくで，放射

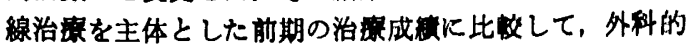

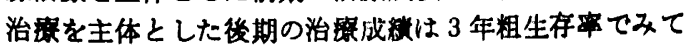
$34.6 \%$ から76.0\%へと著明に向上している。主た外科的

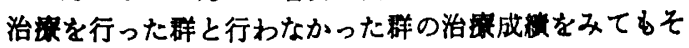
の差は明らかで，前者の 3 年粗生存率が75.0\%であるの に比較して後者では21.1\%と，外科的治强を行った群の

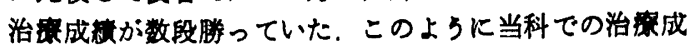

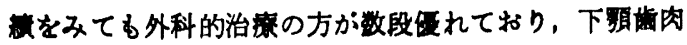
扁平上皮澡に対しては外科的治康を传先ないし主体とす べきと考えられた。

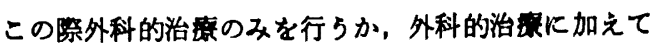

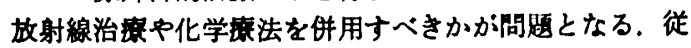

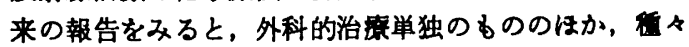
の治哀法を併用したすのが少なくないが，併用箱法の目

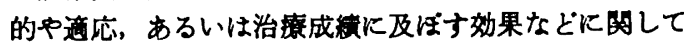
は十分明らかにされていない,

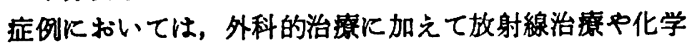
療法を併用したすのは35例と，外科的治度を行った症例 の72.9\%を占めていた。その目的をみると大多数のもの では進行例に対して治療成戴の向上を目的としたもので あったが，一部のすのでは手術に先行して合併症の治療 が必要であったり，患者側あるいは施設側の都合により ただちに手術が行えなかったために，その間嗹㔠の進行 を阻止する目的で行われていた．治療法別の 3 年生存率 は表18に示したごとくで，衍後照射群を除き，手術単独 群とほほ同様な成績であった，一方，初回治港後の残存 ・再発率をみると，手術単独群湾比へて術前照射群や術 前化学潦法群では有意に低率であった。この結果は，下 頻齿肉扁平上皮癌济対する併用療法の効果を示するのと 考えられるか，今回検討したものにおいては各治療群の 症例数が少なく、また病期も異なっており,これらの結 果から併用寮法の効果や递応を論ずることは䔔切でない と思われる.ただしすでに述べたよらに下頻歯肉扁平上 皮癌のなかには進行の早いものがあり，手術後の形態的 障害や機能的障害を可及的に少なくするためにも，何ら かの理由で手術が遅れる症例に対しては術前治㞠を行ら ぺきであると考えている.

次に併用療法として放射線治療と化学寮法のいずれを 用いるべきかが問題となるが，治療成績に関しては両者 間に明らかな差は認められなかった。一方，副障害をみ ると, 術前照射群では多くの症例で創傷治癒不全や移植 皮弁の壊死を生し，再度の手術が必要なるのや，予定し た再建術を行えないすのが少なくなかった。 また約 $1 / 3$ の症例では治療後に放射線骨障害がみられた。このよう に術前照射群においては手術法, とくに再建術に影郬を 与える副障害が比較的高頻度にみられたが, 術前化学療

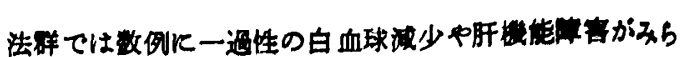

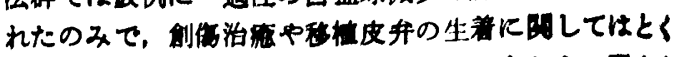
に具常は㥸められなかった。これらのことから，現在当

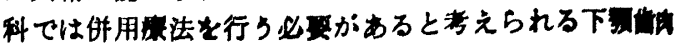

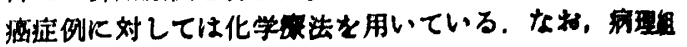

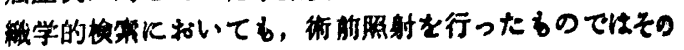

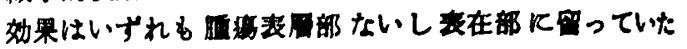

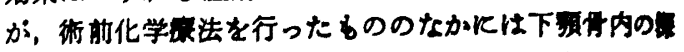

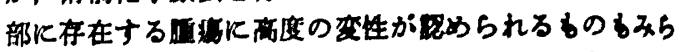

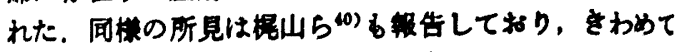
興味ある间罗で改めて轱告する于定である。

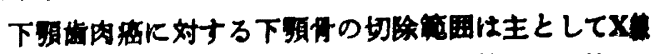

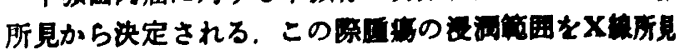

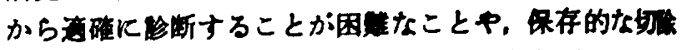

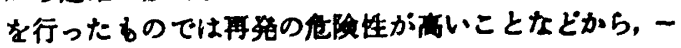
般にかなり多岳の safety margin t势定して切除され

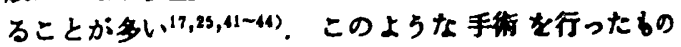

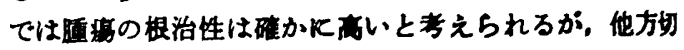
除後に高度な策害を牫するのる少なくない，とくK下頁

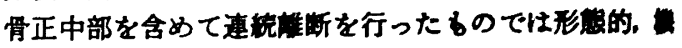
能的㣮害はきわめて高度となるが，今回の食期でる約20 \%の症例では盾湯は正中部に及んでいた。近年これらの 陣害を可及的に少なくする目的で，下䫑骨济洞が明らか でない症例や齿楮骨部に限局している症作火奶しては下 影骨の連続性を保存する辺绿切除街が試みられている

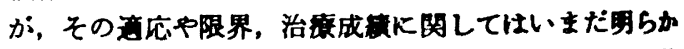

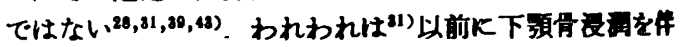

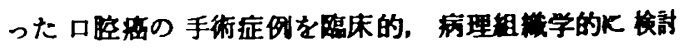
し，多くの症例において下預骨の連続性を保存しらるこ とを確証し，それ以降は可及的に辺很切除街を行ってい

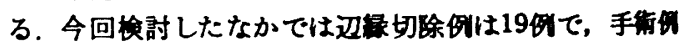

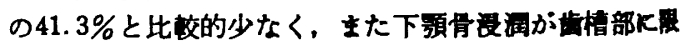

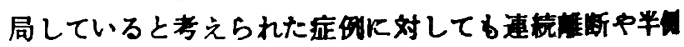
切除を行ったものが少なくないが，これは前回の検討以 前の症例が多いためである.これらの症例扎ける下頡

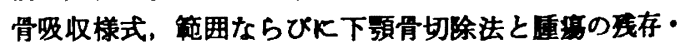

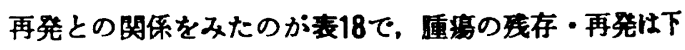
顕骨吸収様式と関釈の深いことが認められる.ナなわち， 下額骨の吸収が明らかでない症例や erosive typeののの

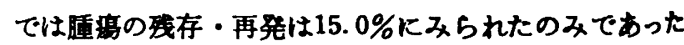
が, invasive type の症例においては41.7\%にみられ, しかも下额骨断端部や下額骨周用に残存・再発がみられ た3例はいずれす invasive type のすのであった. これ らのことは invasive type の吸収を示す症例に対しては safety margin を十分に広く設定する必要があることを 示しており，たとえ下額の吸収が慒部に限局している と考えられる症例においても辺緑切除術の選択は傎重火 行わなければならない，ただしこれらのことは invar sive type の症例においては下顯骨の連続性を保存する 
ことはできないといらことを意味するすのではなく，事 実今回検討したものにおいてる辺緑切除術を行った 6 例 中 3 例では腫場の残存・再発は認められていない。

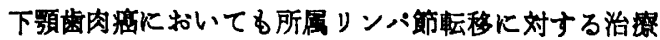
の原則は他の口膑癌と同棣に頱部郭清術を行らことであ $3^{10,25,25,41)}$.この際，顠部郭清術を行万対象あるいは時 期が問題となるが，従来下額齿肉癌においては比校的高

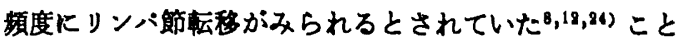
や，転移が明らかなすのにおいては予後不良のことが多 (13,28,28)ことなどから，従来の報告のなかには予防的な 頸部郭清術を推奖するるのるみられる ${ }^{15)}$. 当科活いいて す從来は下顠半側切除例中，舌あるいは咀䏝能などの広

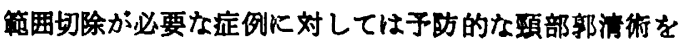
行ってきた．しかし症例を重ねるにつれて，原発随幽の 進展度とリンバ節転移との間化必ずしも予防的頸部郭清 の必要性を支持するような成係のないことが明らかとな り，またすでに述へたよらに下影崡肉癌においてはリ ンバ節転移は従来考えられていたはと高頻度ではないこ となどから，最近では予防的郭清は可及的に 行わない

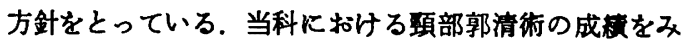
ると、 $\mathrm{N}(+)$ 群, $\mathrm{pN}(+)$ 群のいずれにおいても3 年生 存率は75\%で，頸部郭清術を行っていないN0群とほぼ 同様な成績であった。この結果は，下䫓歯肉癌において は頊部郭清術による救命率が高く，したがって敢えて予 防的郭清を行 万必要がないことを示すむのと思われる.

顠部郭清の範囲としては一般に全頻部郭清術が行われて

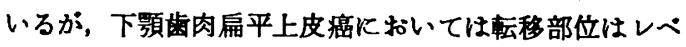
ル1ないしレベル2にとどまるすのが瓦制的に多いこと から、いわゆる supraomohyoid dissection を推奖する すのるみられる年). 今回検討したすのにおいてす転移部 位はいずれるレベル1・2にとどまっており，上述の supraomohyoid dissection を肯定する結果であった. supraomohyoid dissection の利点としては副神経を保存 しらることがあげられている。 われわれは supraomohyoid dissection の経験がなく, その利点や欠点を論ずる 資格はないが，副神経の保存に関する限りでは全頸部郭 清衍においてもそれはと難しいことではない。一方切除 範囲の縮小ならびにそれに伴ら手術時間の短縮は，形態 や機能の保存, 手術の安全性の面から興味ある問題で, 今後検討すべきことと思われる.

\section{結語}

下顥掬肉扁平上皮癌 1 次症例69例を対象として臨床的 観察と治療成績の検討を行い，以下の結果と結論が得ら れた.

1）性別は男性50例，女性19例と，男性飞多かった。

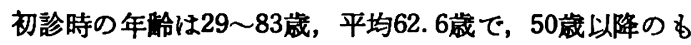
のが94.2\%を占めていた.

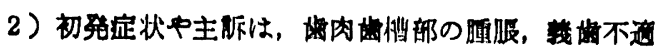

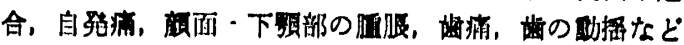

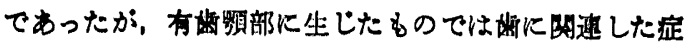
状が多かった。

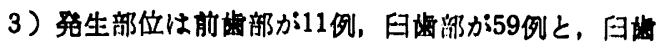
部に生したすのが多く，なかでも大目膡部のすのが全体

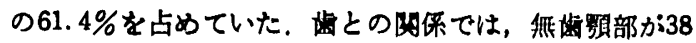
例と過半数を占めていた。

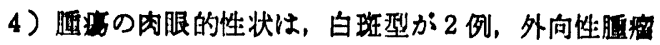

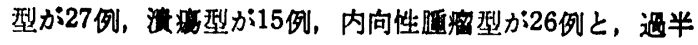
数は内向性增殖傾向を示していた。

5) 初跈時すでに進行したものが多く，肉眼的に齿肉 歯慒部に限局していたものはわずか30\%であった。 また

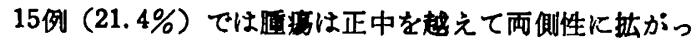
ていた. UICC の病期分類では St. I 症例はなく, St. II $: 21$ 例, St. III $: 11$ 例, St. IV $: 37$ 例 $(53.6 \%)$ であっ た.

6) 初珍時X線所見で骨吸収が認められたものは54例 (78.2\%) で，吸收様式は erosive type が25例，invasive type が 29 例であった。 吸収観囲は, erosive type のむ のでは $80 \%$ 以上が 下頡骨の上 $1 / 3$ に限局していたが, invasive type のものでは過半数に下頻管浸潤か疑われ た.

7) 初診時リンパ節転移を伴っていたものは 30 例 (43.5\%) で,このらち2 例が 2 症例であった。転移 部位は䫑下リンバ節が圧倒的に多く，また全例がレベル 2に留っていた。

8 ）病㮸期間と病期との間には明らかな関係はみられ ず,このことから下影霜肉扁平上皮癌には進行の早いる のと遅いすのとがあると考えられた。

9 ) 一方外科的処直とリンパ節転移との間には明らか な関連がるられ，当科受診前に抜齿や切開などの外科的 処置を受けていた群の初診時転移陽性率が70.6\%であっ たのに比べ, 受けていなかった群では34.6\%であった。

10) 3 年粗生存率は $54.9 \%(28 / 51) ， 3$ 年篮正生存率 は65.1\%(28/43) であった。

11）治療法別の成績をみると，初回治療による腫瘍制 御率, 生存率のいずれをみても，手術を行った群が数段 優れていた。 また放射線治療を主体とした時期の成槙と 外科的治療を主体とした時期の成績を比較しても，後者 での成績が良くこれらの結果から，下䫛歯肉扁平上皮 癌に対しては外科的治療を主体とする治療法を行うべき であると考えられた。

12）手術単独群と術前照射・術前化学療法群との比較

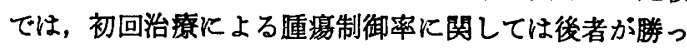
ていたが，生存率では差がなく，併用療法の効果は明ら かにしえなかった。

13）手術併用群に批ける腫煌の残存・再発をみると, invasive type の吸收を示したものに残存・再発が多く, 
invasive type の吸収を示するのに対しては safety margin を十分に忩く設定する必要があると考えられた。

14） N0 群の 3 年敒正生存率は81.1\%，N1〜2 拜では $47.6 \%$ と、リンバ節枟移の有無と生存率との间には明ら

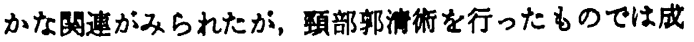

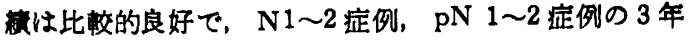
正生存率はともに75.0\%であった。

15）口胫多発性癌が 2 例にみられた。生た再発として 扱った 2 例は口貯多発性癌の可能性が高いと考えられ た。重被期 5 例にみられ、この5ち 3 例は三直癌症例 であった。

\section{引用 文 塥}

1) UICC: TNK-Classification of malignant tumors. 3 rd Ed, UICC, Geneva, 1978, p. 2326.

2) Arthur, K. and Farr, H.W.: Prognostic significance of histologic grade in epidermoid carcinoma of the mouth and pharynx. Am J Surg 124: 489-492 1972.

3) Krause, C.H., Lee, J.G., et al.: Carcinoma of the oral cavity. Arch Otolaryngol 97: 3543581973.

4) 中村平藏, 監修: 最新口腔外科学. 医菌䒚出 版, 東京, 1972, 53頁.

5) Spiro, R.H., Alfonso, A.E., et al.: Cervical Node Metastasis from Epidermoid Carcinoma of the Oral Cavity and Oropharynx. A Critical Assessment of Current Staging. Am J Surg 128: 562-567 1974.

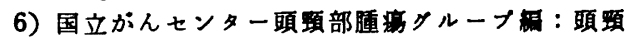
部瘇埸図譜。中山書店, 東京, 1975.

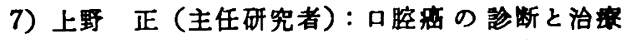
の向上K関する研究. 昭和50年度厚生省がん研 究報告集. 1975, 93-95面.

8) Shear, M., Hawkins, D.M., et al.: The prediction of lymph node metastasis from oral squamous carcinoma. Cancer 37: 1901-1907 1976.

9) Krolls, S.O. and Hoffman, S.: Squamous cell carcinoma of the oral soft tissue: a statistical analysis of 14,253 cases by age, sex and race of patients. IADA 92: 571-574 1976.

10) Shah, J.P., Cendon, R.A., et al.: Carcinoma of the oral cavity. Factors affecting treatment failure at the primary site and neck. Am J Surg 132: 504-507 1976.

11) Berthelsen, A., Hansen, H.S., et al.: Radiation therapy of squamous carcinoma of the floor of mouth and the lower alveolar ridge. $J$ Laryngol Otol 91: 489-499 1977.

12）重松康：口腔癌の放射線治療。日医放会誌 37: 261-285 1977.

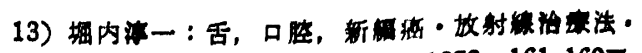

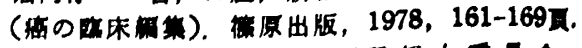

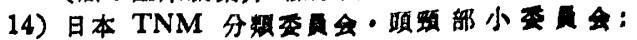

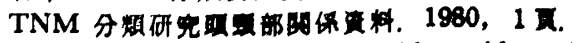

15) Cady, B. and Catlin, D.: Epidermoid carcinoma of the gum. Cancer 23: 551-569 1969.

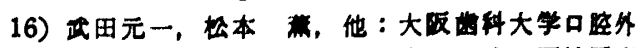

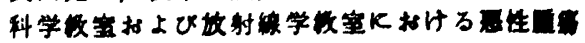

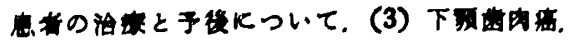
日口外棝 25: 1043-1047 1979.

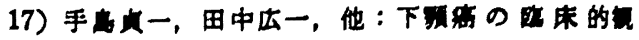
英. 日外望 24:872 1978.

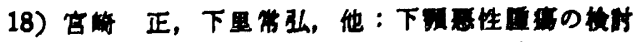

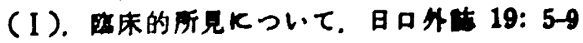
1973.

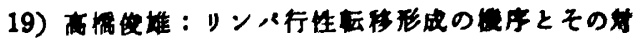

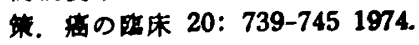

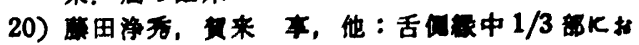

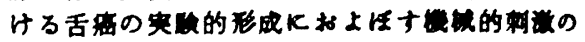

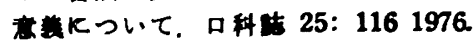

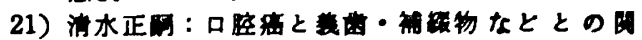
速. 界展望 37: 25-38 1971.

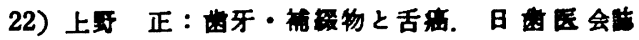
30: 2-10 1977.

23) Nathanson, A., Jakobacon. P.A., et al.: Prognosis of squamous-cell carsinoma of the gums. Acta Otolaryng 75: 301-303 1973.

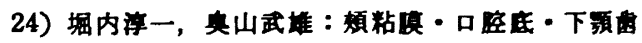

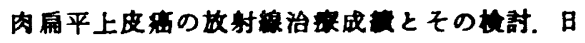
医故会誌 34: 739-751 1974.

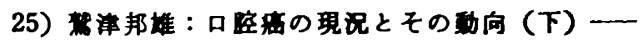
自例を中心下一。界展望 47: 511-522 1976.

26) Backstrom, A., Jakobsson, P.A., et al.: Prognosis of squamous-cell carcinoma of the gums with cytologically verified cervical lymphnode metastases. J Laryngol Otol 89: 391-396 1975.

27) Sharpe, D.T.: The pattern of lymph node metastases in intraoral squamous cell carcinoma. Br J Plast Surg 39: 97-101 1981.

28) Byers, R.M., Newman, R., et al.: Results of treatment for squamous carcinoma of the lowcr gum. Cancer 47: 2236-2238 1981.

29) Swearingen, A.G., McGraw, J.P., et al.: Roentogenologic pathologic correlation of carcinoma of the gingiva involving the mandible. Am J Roentogenol 96: 15-18 1966.

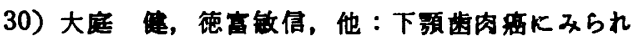
る骨破壊のX線像と組学的所見との比硬 究. 日医放会誌 34：820-834 1974.

31）戸挥靖則，富田喜内，他：下预骨浸洞を伴5口 腔海の臨床的・病理組学的研究: 下預骨の切 除筑囲について。旺外誌 29: 811-828 1983.

32) Silverman, S. and Griffith, M.: Smoking cha- 
racteristics of patients with oral carcinoma and the risk for second primary carcinoma. JADA 85: 637-640 1972.

33) Konrad, H.R., Canalis, R.F., et al.: Epidermoid Carcinoma of the Palate. Arch Otolaryngol 104: 208-212 1978.

34) Vegers, J.W.M., Show, G.B., et al.: Squamous cell carcinoma of the buccal mucosa. A review of 85 cases. Arch Otolaryngol 105: 1921979.

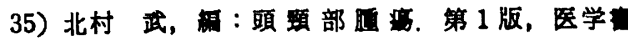
院，東京，1971，212-238頁。

36) Fayos, J.V.: Carcinoma of the mandible. Result of radiation therapy. Acta Radiol Ther 12: 376-386 1973.

37) Lee, E.S. and Wilson, J.S.P.: Carcinoma involving the lower alveolus. Brit J Surg 60: 85-106 1973.

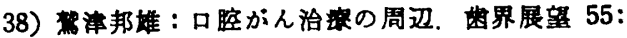

789-801 1980.

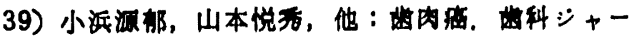
ナル 14: 663-676 1981.

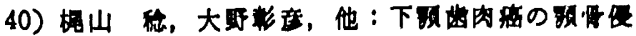

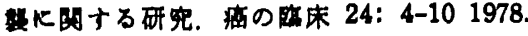

41) MacComb, W.S. and Fletcher, G.H.: Cancer of the head and neck. Williams \& Wilkins, Baltimore, 1967, 89页.

42) Yonemoto, R.H., Ching, P.T., et al.: The Composite Operation in Cancer of the Head and Neck. (Commando Procedure) Arch Surg 104: 809-813 1972.

43) Barbosa, J.F.: Surgical Treatment of Head and Neck Tumors. Grune \& Stretton, New York, 1974, p 81.

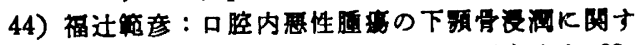

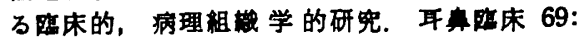
439-451 1976. 